\title{
NOTES ON VELIGERS OF JAPANESE OPISTHOBRANCHS (7)
}

$\operatorname{AUTHOR}(S)$ :

Hamatani, Iwao

\section{CITATION:}

Hamatani, Iwao. NOTES ON VELIGERS OF JAPANESE

OPISTHOBRANCHS (7). PUBLICATIONS OF THE SETO MARINE

BIOLOGICAL LABORATORY 1967, 15(2): 121-131

\section{ISSUE DATE:}

1967-09-11

URL:

http://hdl.handle.net/2433/175461

RIGHT: 


\title{
NOTES ON VELIGERS OF JAPANESE OPISTHOBRANCHS (7)
}

\author{
IWAO HAMATANI \\ Biological Laboratory, Ôsaka Kyôiku University, Ôsaka. \\ (Fuzoku Tennôji Senior High School attached to the University)
}

With 11 Text-figures

Since the present series of observations on the veligers of Japanese Opisthobranchs was started in 1960, six papers comprising the detailed descriptions of veligers of eighteen species have been published, and here is presented the seventh paper, in which the following three more species are given: Elysia (Elysia) trisinuata BABA of Elysiidae (Ord. Sacoglossa), and Dermatobranchus (Dermatobranchus) striatellus BABA of Arminidae and Aeolidiella japonica Eliot of Facelinidae, both belonging to Ord. Nudibranchia. All of these species were collected from the seashore near the Seto Marine Biological Laboratory.

\section{Elysia (Elysia) trisinuata BABA}

(Figs. 1-3)

This species is found most frequently on green algae of the genus Codium ( $C$. pugniformis, C. cylindricum and etc.) growing near the low water mark of the shore near the Seto Marine Biological Laboratory, usually several individuals per alga.

On July 29, 1964, a single specimen and two egg-masses were collected from the
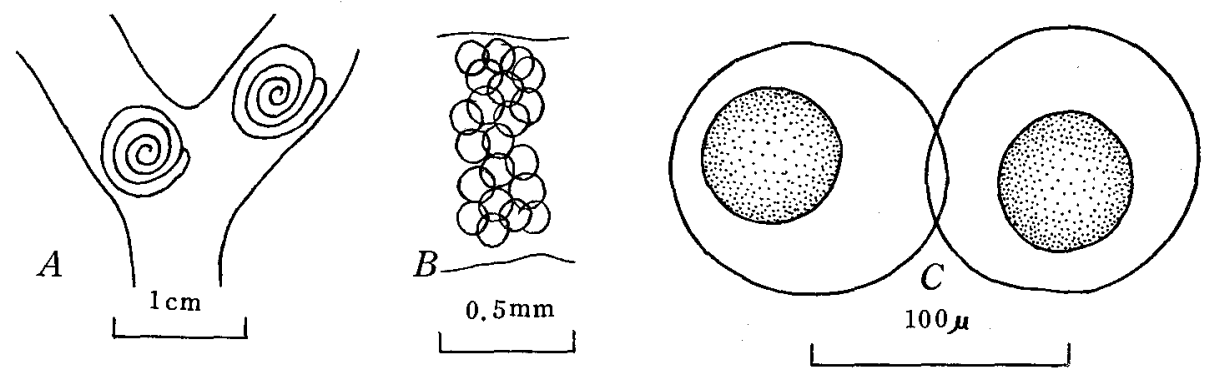

Fig. 1. Elysia (Elysia) trisinuata BABA

A. Egg-masses laid on Codium cylindricum.

B. A part of the egg-ribbon showing the arrangement of egg-capsules.

C. Two eggs.

Contributions from the Seto Marine Biological Laboratory, No. 467.

Publ. Seto Mar. Biol. Lab., XV (2), 121-131, 1967. (Article 7) 
surface of Codium cylindricum; the water temperature was $23^{\circ} \mathrm{C}$ at that time. The egg-masses were kept in a glass-vessel and further observations were made on one of them. The egg-masses (Fig. 1, A-B) are each a faintly yellowish green ribbon coiled sinistrally about 3 times to form a spiral with a $4 \mathrm{~mm}$ diameter. Only a single ovum (Fig. 1, C) is contained in each egg-capsule. The diameter of egg-capsules is 77 to $85 \mu$ and that of ova is about $46 \mu$.

Early development: When the egg-masses were brought in the laboratory, it was found that the embryos were in the earliest stage of the veliger; the statocysts were discernible already in the veliger's body, but the distinct formation of eyes was not yet achieved; a hump of the velar organ with long cilia and that of a foot were

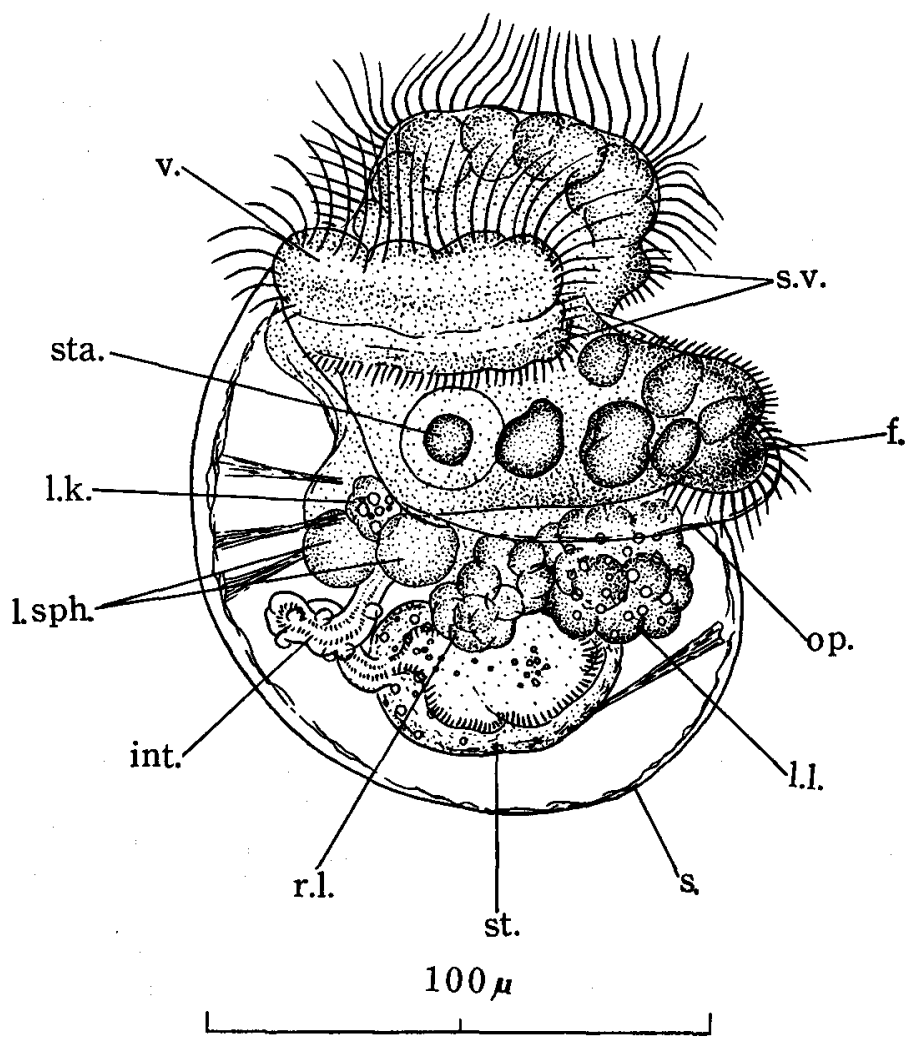

Fig. 2. Elysia (Elysia) trisinuata BABA

Newly hatched veliger, from the right side.

Abbreviations: e. ... eye, e.i. ... entrance to the intestine, f. ... foot, $h, \ldots$ heart, (h.) ... the position of heart beating, int. ... intestine, 1.k. ... larval kidney, 1.1. ... left liver, l.sph. ... large spherical body, oes. ... oesophagus, op. ... operculum, r.b. ... rod-like bodies, r.l. ... right liver, r.m. ... retractor muscle, s. ... shell, s.c. ... sensory cilia, s.sph. ... small spherical body, st. ... stomach, sta. ... statocyst, s.v. ... sub-velum, v. ... velum. 
visible, and the visceral mass contained many large yalk cells. On the second day after the collecting, the velum hump was divided into the right and left parts, the foot with operculum was visible and respective visceral organs were found in formation; and thus the outline of veligers was nearly completed. The larvae were found escaping from their capsules on the fourth day and set out their free swimming life as plankton; the water temperature was $27.5^{\circ} \mathrm{C}$ at that time.

Veligers: The newly hatched veligers (Fig. 2) are roundish in outline and measured about $140 \mu$ in long diameter. They are transparent and colourless. No pigmentation is observed in any visceral organs. The veliger's shell (Fig. 3, A) is roundish, sinistral, transparent and colourless, and measured about $100 \mu$ in height and width in an examined rather small specimen. Many sculptures consisting of very minute dots are visible over the whole surface of the shell, especially densely in its axial half. The umbilicus is not present. The operculum (Fig. 3, B) is roughly circular in shape, 58 by $75 \mu$ in dimension in an examined specimen and with a spiral line coiling about 2 times, which is seen with difficulty. The subvelum is distinct, both the velum and subvelum are devoid of any refracting granules in the tissue. The statocysts are distinct, but the eyes absent. The foot has a dense cover of short cilia all over the surface, especially the median part stretching from the mouth to the tip of the foot bears a strong ciliation; several long cilia probably of a sensory function, are visible at the tip and on a part of either side of the foot. The tip of the foot does not protrude beyond the edge of the operculum. The tissue of the foot contains three pairs of large cells which assume a spindle shape in frontal view, they are probably of a secretory function. The stomach is large and contains several refracting granules, but none of the rod-like bodies are observed in its tissue. There
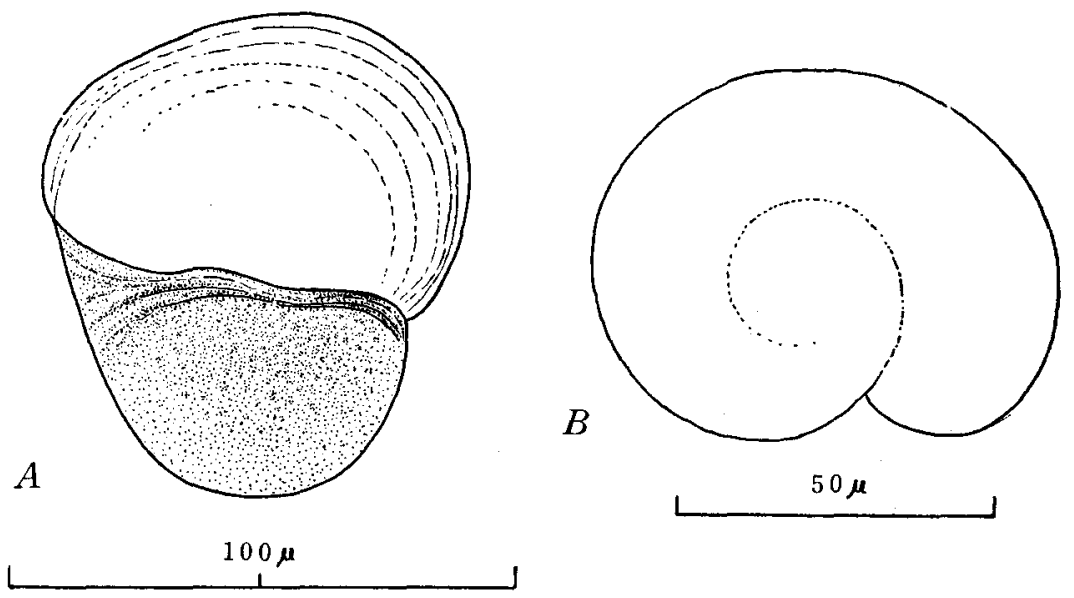

Fig. 3. Elysia (Elysia) trisinuata BABA

A. Larval shell, from the ventral side.

B. Operculum of larval shell. 
are two liver-lobes, the left and the right; both are colourless and consist of very large cells, in which many small refracting granules are visible in the larger left liver-lobe, but none of them in the smaller right one. The intestine with some warty cells on its outer surface starts from the right dorsal part of the stomach and forms a single twist before it reaches the anus. Near the anus a roundish organ, probably larval kidney, is situated on the right side of the body. The organ is unpigmented and contains some refracting granules. Two large prominent spherical bodies are visible on the right side of the body just near the larval kidney. These bodies are colourless, translucent, but no refracting granules in them. It is strange, but such organs as those found in this species are not observed in another species of the same genus, E. hamatanii, in which two roundish organs, probably larval kidneys, containing several refracting granules were observed just near the anus by the present author (HAMATANI, 1960). The exact homology between those organs of $E$. hamatanii and the two large prominant spherical bodies in the present species is still uncertain.

\section{Dermatobranchus (Dermatobranchus) striatellus BABA}

(Figs. 4-7)

This tiny species is not rare on the shore near the Seto Marine Biological Laboratory. Several specimens, about $10 \mathrm{~mm}$ long in an average, were collected on August 14, 1965, from the surface of a stone near the lowest tidal mark at Yuzaki, south of the Seto Marine Biological Laboratory.

One of these animals laid an egg-mass on the bottom of a glass-vessel on the early morning of August 21, the seventh day after the collecting. The egg-mass (Fig. 4, A) is of the form of a small glass cup, with a short stalk by which the whole mass is fastened to the substratum; short diameter of the mass $1.7 \mathrm{~mm}$ and long diameter $3 \mathrm{~mm}$. The colour of the mass is whitish, though faintly tinted orange. The egg-capsule (Fig. 4, B) of the newly laid egg-mass is oval in outline and $215 \mu$ in diameter for example. Only a single ovum, $170 \mu$ in diameter, is contained in each capsule.

Early development: Further observations of this egg-mass were done under the room temperature of $24^{\circ} \mathrm{C}$. On the next day of the oviposition, the embryos were brought to the trochophoral stage. On the third day they reached the earliest stage of the veliger; the foot with operculum was discerned already, but no visceral organs except for the statocysts were observed owing to the opacity of the embryo. On the sixth day, the embryos seem to reach the last veliger stage.

Veliger and young individual: In this only one case of observation, the veligers spent their whole period in the egg-capsule as an intra-capsular veliger. The veligers (Fig. 5, A-B) are wholly light brownish in colour, but become gradually darker with the development. Respective visceral organs are hardly visible through the opaque body wall. Both the velum and subvelum are present as in other species; the velum is 

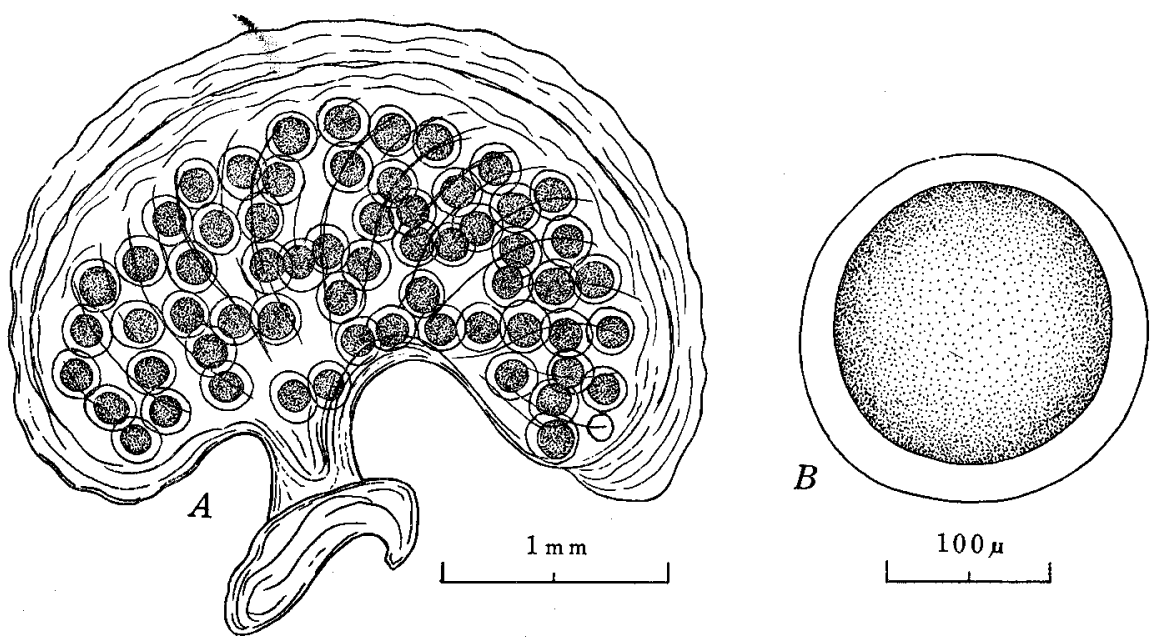

Fig. 4. Dermatobranchus (Dermatobranchus) striatellus BABA

A. Newly laid egg-mass.

B. Ovum in the capsule.

unpigmented and contains a number of large refracting granules arranged in a row along the edge. The eyes with lens are very distinct, as they are pigmented in reddish brown on the eighth day after the oviposition; but the pigment colour turns blackish on the next day. The statocysts are well marked as usual. The foot with a dense cover of short cilia all over the surface is yellowish brown in colour, large and well developed. There are several long cilia, probably of a sensory function, at the tip which slightly protrudes out from the distal margin of the foot. The vesicle, namely the larval heart, makes its appearance a few days before the hatching on the dorsal side of the body slightly right to the middle. The larval shell (Fig. 6, A) is roughly ovoid in outline, with a long diameter of $210 \mu$ and a short diameter of $150 \mu$ in an examined specimen, sinistral, slightly brownish in colour, and not transparent. It is furnished densely with minute dots over the whole surface. Particularly many small patches of ornaments are distributed in the axial half of the shell, especially densely near the aperture. A number of fine growth lines are visible in the half of the shell on the side of the aperture, but no umbilicus is formed. A peg is projected out from the lower end of the inner side of the columellar thickening. The operculum (Fig. $6, \mathrm{~B})$ is semi-circular in shape, 80 by $100 \mu$ in dimension in a measured specimen, and has a spiral sculpture coiling about 2 times. It is colourless and transparent. The hatching out of larvae began on the tenth day after the egg-laying and continued for two days, and the newly hatched larvae settled as soon as they escaped from their capsule. It is very interesting that the hatching larvae leave their shells within the gelatinous layer of the egg-mass, thus they crawled out on the bottom of glassvessel as a young adult form (Fig. 7, A-B). In this case, any free pelagic stage of 

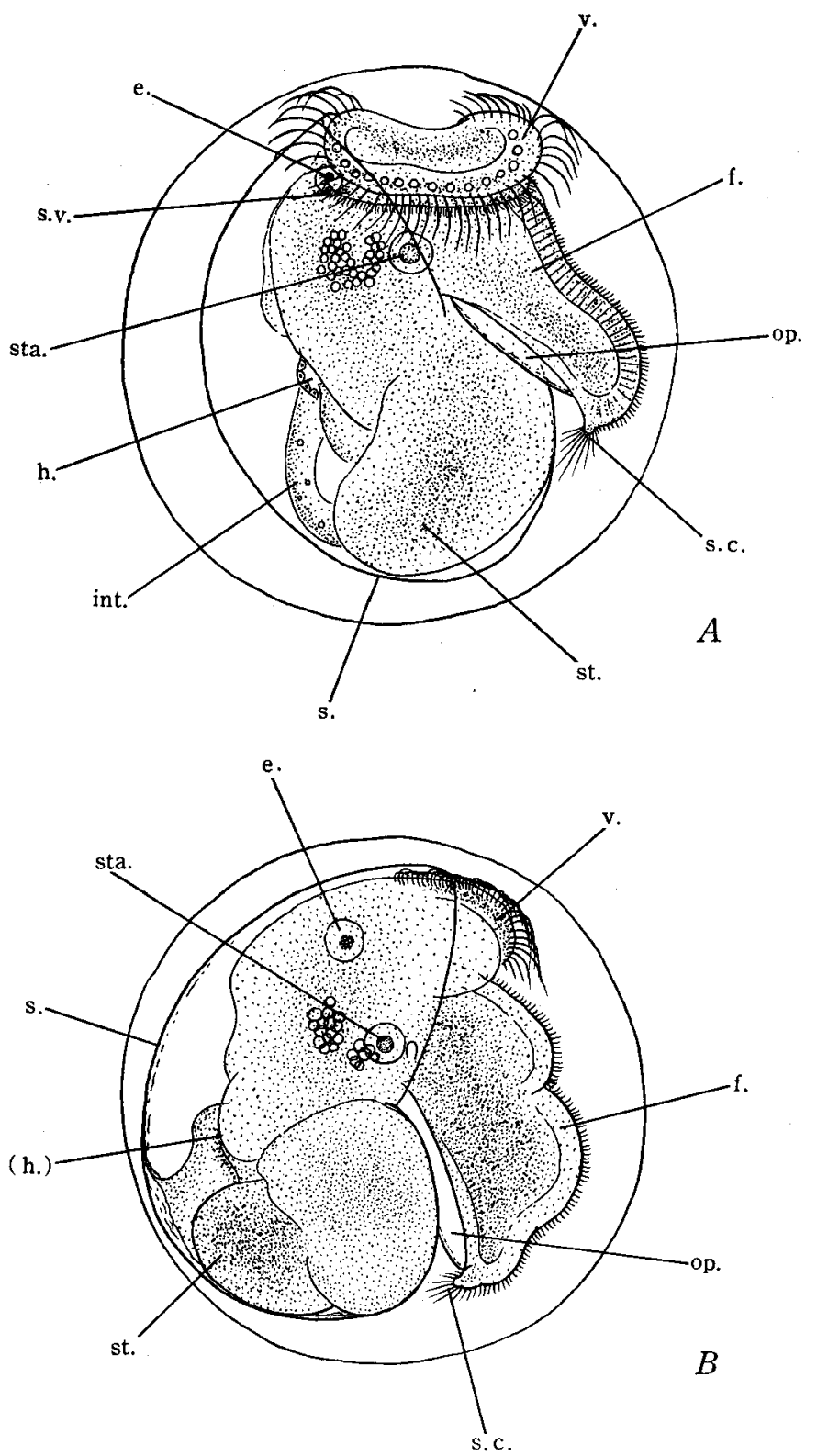

Fig. 5. Dermatobranchus (Dermatobranchus) striatellus BABA

A. Intra-capsular veliger 8 days old, from the right side.

B. Intra-capsular veliger 9 days old, from the right side.

(For abbreviations see Fig. 2) 

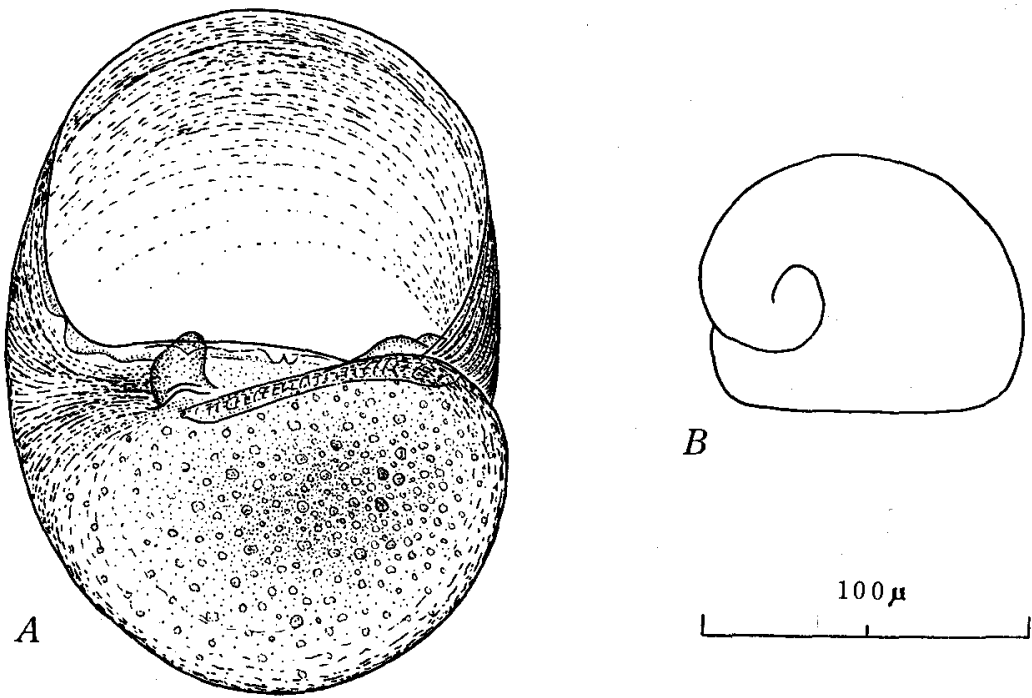

Fig. 6. Dermatobranchus (Dermatobranchus) striatellus BABA

A. Larval shell, from the ventral side.

B. Operculum of larval shell.
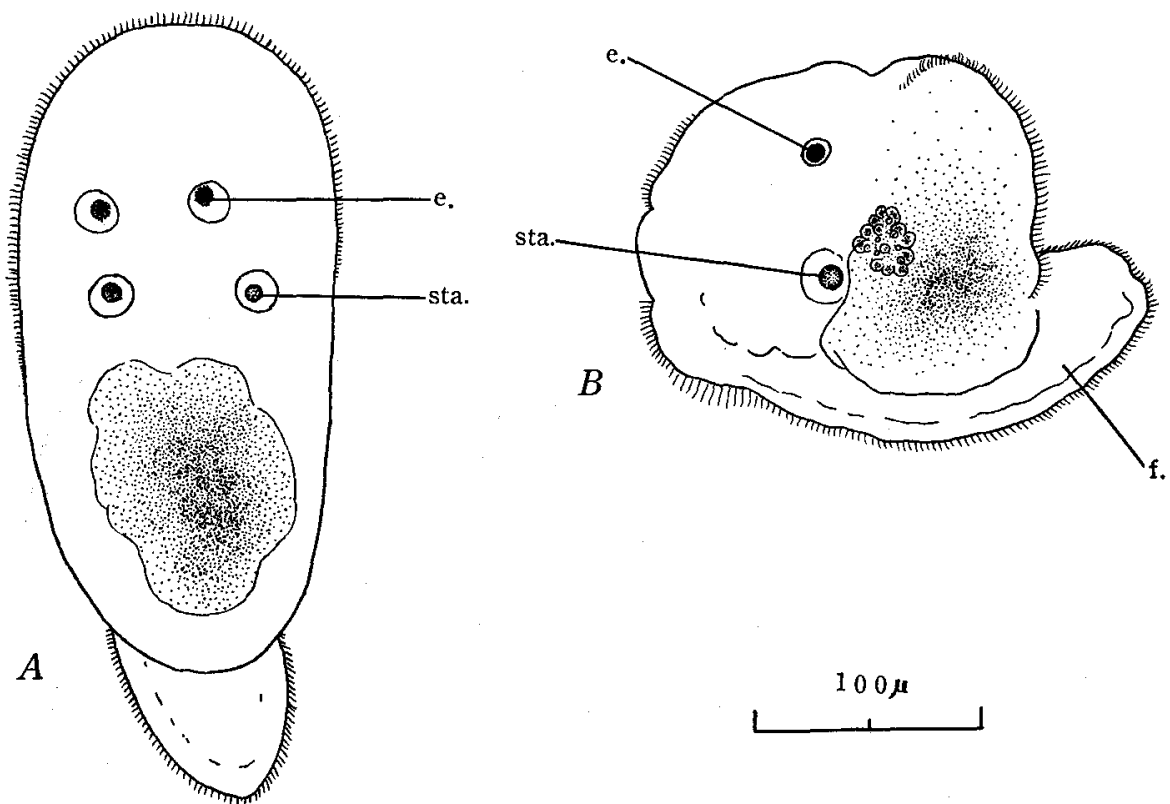

Fig. 7. Dermatobranchus (Dermatobranchus) striatellus BABA

Newly hatched young individuals, extended (A) and contracted (B).

(For abbreviations see Fig. 2) 
veliger can not be seen at all as in the case of such an aeolid species as Embletonia pallida (Alder \& Hancock) from Copenhagen observed by Rasmussen (1944), although it is not impossible that a very short free swimming veliger stage can be seen in the present species as in the case of $E$. pallida from Isefjord observed by Rasmussen.

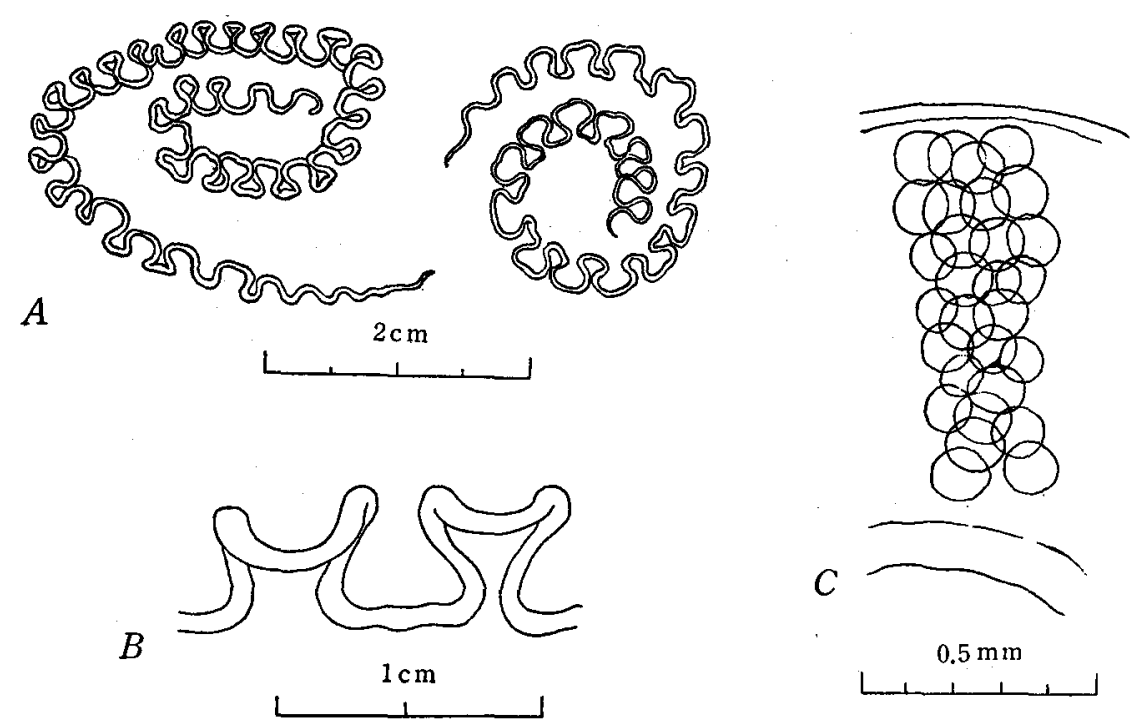

A. Egg-masses.

B. A part of the egg-mass.

C. A part of the egg-filament showing the arrangement of egg-capsules.
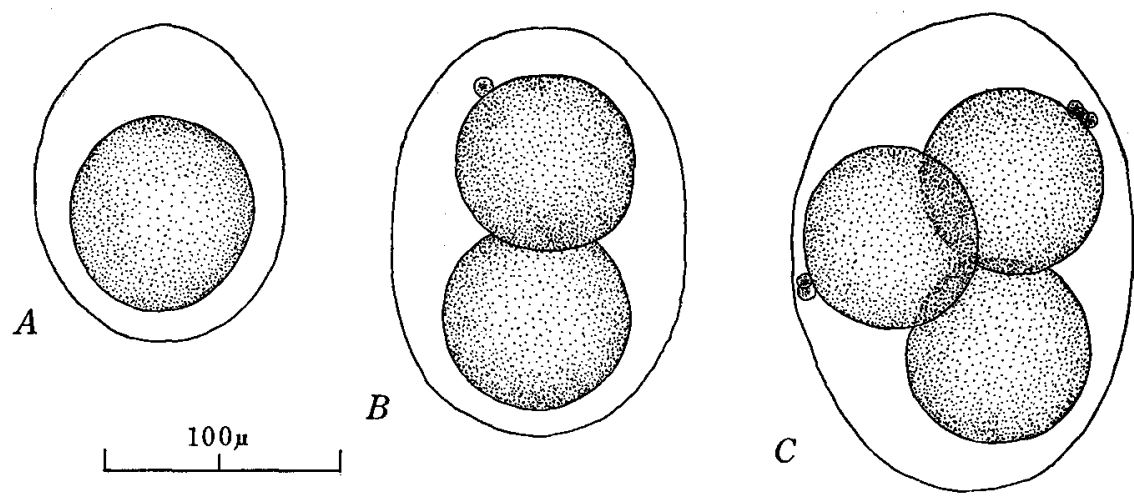

Fig. 9. Aeolidiella japonica Eц.1oT

A. Egg-capsule with one ovum.

B. Egg-capsule with two ova.

C. Egg-capsule with three ova. 


\section{Aeolidiella japonica ELIOT}

(Figs. 8-11)

This species is found commonly on the under side of stones near the low water mark in the vicinity of the Seto Marine Biological Laboratory. On August 13, 1965, several adults in spawning wer collected from the under side of a stone. Three days later, some of them spawned again an egg-mass on the bottom of a glass-vessel, which was quite the same as that observed in the sea. The egg-mass (Fig. 8, A-C) is a long sinuous filament loosely coiled sinistrally one and a half to three times; the sinuation consists of a serics of somewhat triangular loops as shown in fig. 8, A and B. The whole spiral is slightly pinkish and its diameter measures $20 \mathrm{~mm}$ in an average. Each egg-capsule contains 1 to 4 ova (Fig. 9, A-C). The size of eggcapsule varies from 100 by $125 \mu$ to 145 by $190 \mu$ and that of ovum ranges from 77 to $85 \mu$ in diameter.

Early development: Further observations were made on the above-mentioned egg-mass obtained in the laboratory under the room temperature regulated at $24^{\circ} \mathrm{C}$. The embryos reached the gastrula stage on the next day of the oviposition, and advanced to the trochophoral stage on the third day. It was on the fourth day when all the embryos assumed the earliest veliger stage; at this time the embryos have two velum humps with rather long cilia and the foot hump not yet with operculum, but the visceral organs are not differentiated yet except for the statocysts which are distinct already. On the fifth day the embryos attained nearly the completed veligers, and on the eighth day they hatched out from the capsule as free swimming veligers.

Veligers: The newly hatched veligers (Fig. 10) are roundish in shape and about 120 by $145 \mu$ in size. The whole body is faintly yellow and transparent. The larval shell (Fig. 11, A-B) is sinistral as usual, elongated ovoid in outline and 93 by $140 \mu$ in dimension for instance. It is colourless, but it has many sculptures consisting of very minute dots over the whole surface. There is no peg nor any swallen portion along the inner part of the columellar thickening. The umbilicus is not formed, either. There is an operculum really, but it is quite colourless and so thin that it is very difficult to observe it under the usual microscope. It seems to be semi-cricular in shape, so far as the author's observation goes. The velum and subvelum are formed distinctly. The velum and often the subvelum, too, have respectively several refracting granules in the tissue. A pair of statocysts are well marked. The eyes are not visible. The unknown organs, which are formed on the right side of the body just behind the anus, provisionally called "the small spherical bodies" in this paper (s. sph. in fig. 10) and containing several small granules within, might be the rudimentary eyes. The foot is covered with numerous rather long cilia all over the surface and has several characteristic cells in its tissue. The stomach is transparent and has several rod-like bodies in the wall of the ventral side. There are two liver lobes, the left and the right, both with many refracting granules in 


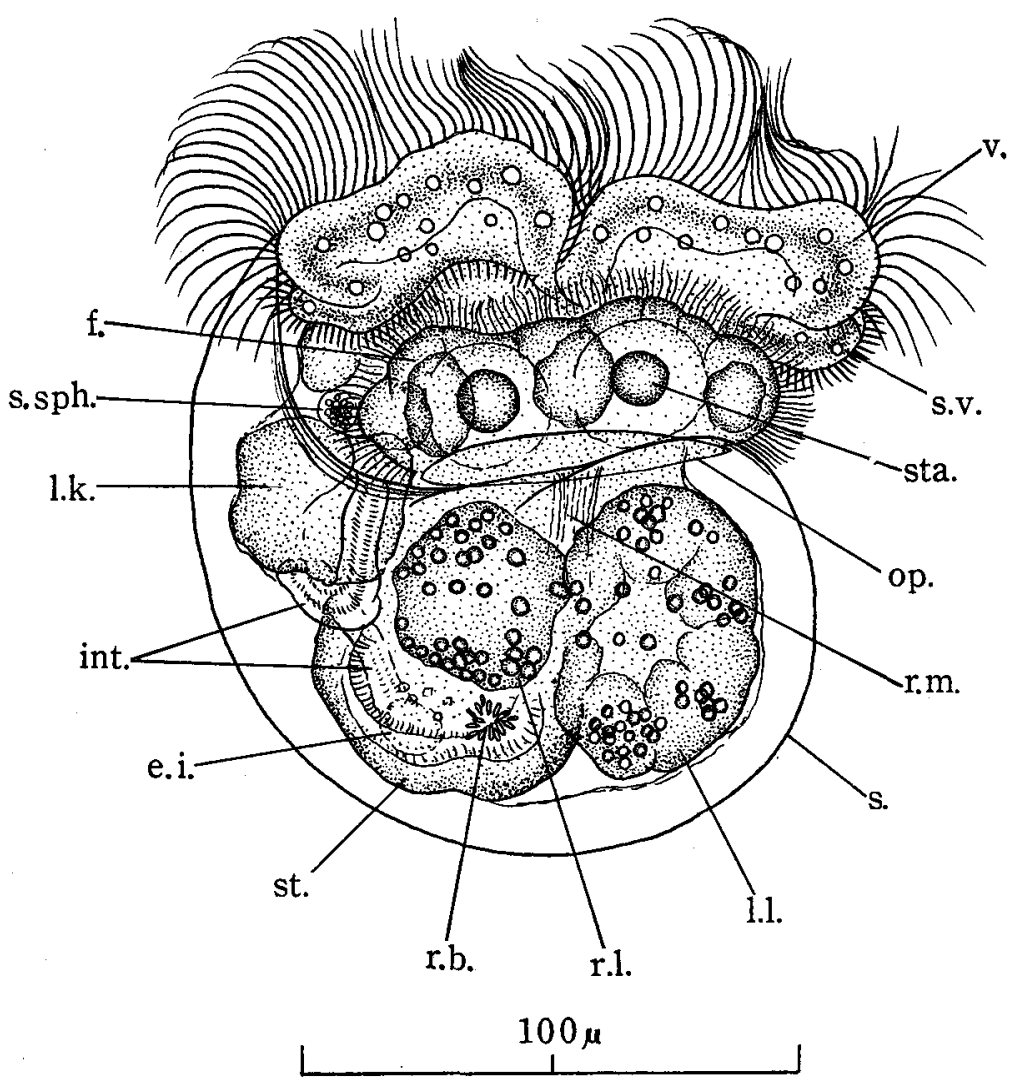

Fig. 10. Aeolidiella japonica ELIOT.

Newly hatched veliger, from the ventral side. (For abbreviations see Fig. 2)
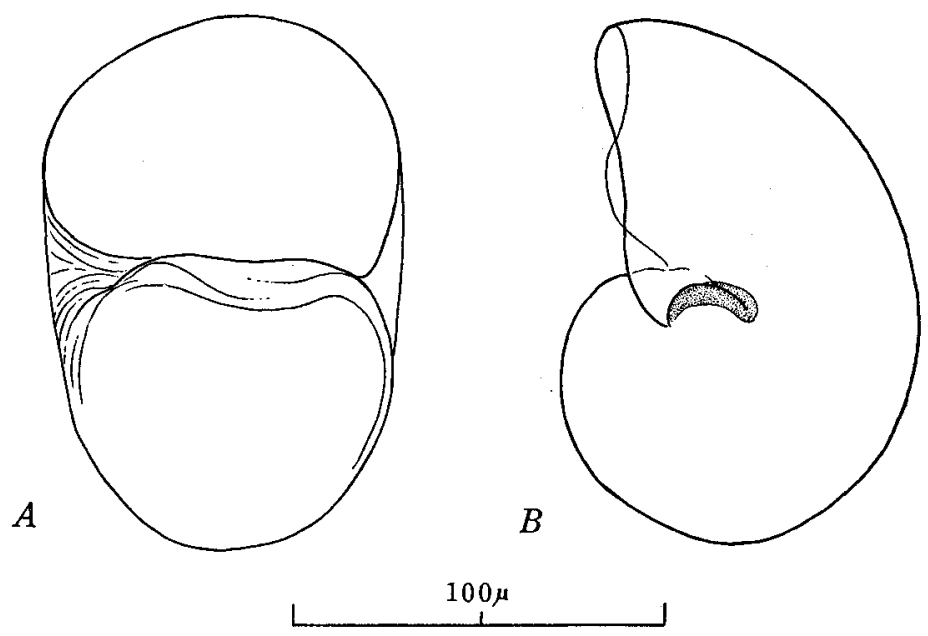

Fig. 11. Aeolidiella japonica Ецioт

A. Larval shell, from the ventral side.

B. Larval shell, from the apex. 
their tissue. The central portion of the left lobe looks empty and translucent. The right lobe is smaller than the left and almost transparent. The intestine with a single simple curve starts from the dorsal side of the stomach and leads to the anus at the edge of the shell on the right side of the veliger's body. No warty cells are formed on the surface of the intestine. There is a large larval kidney just near the anus, which is unpigmented.

\section{LITERATURE GITED}

Baba, K., Hamatani, I. and Hisai, K. 1956. Observations on the spawning habits of some of the Japanese Opisthobranchia (II). Publ. Seto Mar. Biol. Lab., Vol. 5, No. 2.

Hamatani, I. 1960. Notes on veligers of Japanese opisthobranchs (1). Publ. Seto Mar. Biol. Lab., Vol. 8, No. 1.

Rasmussen, E. 1944. Faunistic and biological notes on marine invertebrates I. Vidensk. Medd. fra Dansk naturh. Foren., Bd. 106.

Thorson, G. 1946. Reproduction and larval development of Danish marine bottom invertebrates. Medd. Kommiss. Danmarks Fisk. Havunders., Plankton, Vol. 4, No. 1. 